\title{
Prediction Level of the Fourth Grade Students' Scientific Attitudes on Reflective Thinking Skills for Problem Solving
}

\author{
Eray Ĕğmir \& Ijlal Ocak \\ Afyon Kocatepe University, Faculty of Education, Afyonkarahisar, TURKEY
}

Received: 13 May 2020 • Accepted: 16 July 2020 • Published Online: 19 August 2020

\begin{abstract}
In this study, the prediction level of the fourth-grade students' scientific attitudes on reflective thinking skills for problem solving was examined. The research was conducted using the correlational survey model and the sample of the study consisted of 468 students identified through simple random sampling. According to the findings the students had a low level of reflective thinking skills for problem solving and scientific attitudes. It can be said that there is a significant and positive correlation between the fourth-grade students' scientific attitudes with reflective thinking skills for problem solving. Besides, while the model established for the prediction of the reflective thinking of the fourth-grade students by the scientific attitude is significant, reflective thinking for problem solving of the fourth-grade students was strongly explained by scientific attitudes.
\end{abstract}

Keywords: attitude, scientific attitude, reflective thinking, problem solving, fourth grade students.

\section{Introduction}

Contemporary thoughts about learning have turned learning environments into a structure where the student is at the center and where individual differences about the student are considered. For this reason, the characteristics of students such as interest, need, attitude, expectation, and academic-self have a significant effect on both the theoretical and practical directions of the teaching process. Metacognition is one of the important concepts that emerges in learning environment and significantly predicts students' internal concepts such as attitudes and motivation to learn and their preferences towards learning strategies. According to Reeve and Brown (1985), metacognition is the ability of the individuals to control and direct their own cognitive activities. Metacognition is an important phenomenon that supports the purpose of creating independent learners that contemporary education systems care about (Kramarski, 2008; Mevarech \& Amrany, 2008).

In this context, the individual should determine which way he/she learned best, and what aspects he/she should change or strengthen in the learning process and raise the level of learning through these regulations. At this point, reflective thinking skill, which is frequently emphasized in the current curriculum, appears. Unver (2003) defines reflective thinking as the thinking process to reveal the positive and negative situations related to the teaching or learning

(C) Authors. Terms and conditions of Creative Commons Attribution 4.0 International (CC BY 4.0) apply. Correspondence: Eray Eğmir, Afyon Kocatepe University, Faculty of Education, Afyonkarahisar, TURKEY. E-mail: eegmir@aku.edu.tr. 
E. Eğmir \& İ. Ocak - Prediction Level of the Fourth Grade Students' Scientific Attitudes...

method and to solve the problems related to method or level of learning. In contemporary education systems it is very important to be aware of the problems and to engage in the thinking process to solve these problems. Reflective thinking in this regard appears as a thinking skill that supports problem solving.

- Students have a low level of reflective thinking skills for problem solving and sub-dimensions. Students have a low level of scientific attitudes, too.

- While students' reflective thinking skills for problem solving and scientific attitudes do not differ significantly in terms of gender, family income level and father education level, the students' reflective thinking skills for problem solving and scientific attitudes differ significantly in terms of mother education level, first semester grade and mathematics exam grade.

- There is a significant and positive correlation between the fourth-grade students' scientific attitudes with reflective thinking skills for problem solving and sub-dimensions.

- Compound effects of variables except family income level, mother education level and first semester grade with scientific attitude level were not significant.

- While the model established for the prediction of the reflective thinking of the fourth-grade students by the scientific attitude is significant, reflective thinking for problem solving of the fourth-grade students was strongly explained by scientific attitudes.

Problem solving skill is one of the important skills that education systems consider important in the light of current developments. According to Gagne (1980), it should be known that the teaching method of the 21st century is problem solving. According to Bingham (2004: 24), the problem is the obstacle that confronts the individual's existing skills used to achieve the desired goal. So, problem solving is to find new solutions by going beyond the simple application of the rules learned through previous experiences to solve a problem (Korkut, 2002). Problem solving skill is to develop the ability to limit and understand when a problem is encountered, to choose the appropriate method for its solution, to use this method, and to analyze the results. When this skill is acquired, the individual gets the habit of acting with a problem solving approach to explain the events around (Altun, 2002). At this point, the first and most important activity that an individual should do in order to show problem solving skills is "thinking".

The perception of the problem starts the thinking activity, the solution of the problem turns into a goal for the individual, and this purpose directs the thinking activity (Kalayc1, 2001). While some problems have the right answers or certain solutions, some other do not have. The solution of these problems requires interdisciplinary knowledge, multi-faceted thinking, and creativity (Senemoğlu, 1997). In this process, the individual needs to employ higher-order thinking activities and must be creative, reflective, critical, and analytical (Bilen, 1996).

Due to its nature, problem solving skills are both disciplinary and interdisciplinary. One of the areas where this skill has an important function due to its structure is science. When the Science Education curriculum published by the Ministry of Education (2018) is examined, particular emphasis is placed on creating students who produce knowledge, use it functionally in life, solve problems, think critically, have communication skills, empathize, and contribute to society and culture. Students' level of using problem solving skills or functioning within a field is closely related to their attitudes towards this field.

Attitudes are defined as a predisposition to respond positively or negatively to things, people, places, or ideas (Simpson et al., 1994). Attitude is best viewed as a set of affective reactions towards an object, derived from concepts of beliefs that the individual has, and predisposing the individual to behave in a certain manner towards that object. In science and science education, the major division has been in terms of scientific attitude which is directly related to someone's 
disposition towards scientific research or activity. In other words, it is the inclination to value empirical evidence as the basis of belief on science (Gardner, 1975; Johnston, 1996; OECD, 2017). Munby (1983) defined scientific attitude as the thinking pattern and characteristic of scientists. To be scientific means that one has such attitudes as curiosity, rationality, open-mindedness, critical-mindedness, objectivity, honesty, humility, and willingness to suspend judgment.

Many researchers indicated that students' attitude and interests could play substantial role on their science achievement (Adodo \& Gbore, 2012; Simpson \& Oliver, 1990; Wilson, 1983). According to Osman, Iksan \& Halim (2007), scientific attitude can support scientific learning and enhance the performance of scientific activity. Gokul and Malliga (2015) mentioned that scientific attitude is the most important outcome in science teaching, and it is equally important as the scientific knowledge. Similarly, Bloom (1976) reported that attitude accounted for up to $25 \%$ of the variability in students' achievement scores. Knowing students' scientific attitudes and attitudes towards science is important in structuring the learning environment. Well-structured learning environments both increase achievement and contribute to the positive change of attitudes (Olasehinde \& Olatoye, 2014).

So, in this study, whether there was a significant correlation between these two concepts was investigated. Also, the fourth-grade students' scientific attitudes and reflective thinking skill levels of problem solving were determined. Whether the fourth-grade students' scientific attitudes and reflective thinking skill levels of problem solving showed a significant difference in terms of gender, family income level, mother education level, father education level, first semester average grade, and last mathematics exam grade was also examined.

\section{Method \\ 2.1 Research design}

The research was conducted using the correlational survey model. The correlational survey model is important to reveal relationships between variables and to determine the levels of these relationships (Karasar, 2016: 114). Moreover, the correlational survey provides the necessary clues for conducting higher-level research on a relationship (Büyüköztürk, 2016: 185).

\subsection{Population and sample}

The population of the study consisted of the fourth-grade students studying in Afyonkarahisar city center. The sample of the study consisted of 468 students identified through simple random sampling. The distribution of the determined sample according to some variables is presented in Table 1.

Table 1. Distribution of the sample

\begin{tabular}{llll}
\hline Variable & & f & \% \\
\hline \multirow{2}{*}{ Gender } & Female & 238 & 50.9 \\
\cline { 2 - 4 } Family income level & Male & 230 & 49.1 \\
\cline { 2 - 4 } & Low (under 1500 TL) & 112 & 23.9 \\
\cline { 2 - 4 } & Average (1501-3000 TL) & 242 & 51.7 \\
\cline { 2 - 4 } Mother education level & High (3001 TL and above) & 114 & 24.4 \\
\cline { 2 - 4 } & Primary School & 166 & 35.5 \\
\cline { 2 - 4 } & Secondary School & 124 & 26.5 \\
\cline { 2 - 4 } Father education level & High School & 101 & 21.6 \\
\cline { 2 - 4 } & Undergraduate & 79 & 16.5 \\
\cline { 2 - 4 } & Primary School & 109 & 23.3 \\
\hline
\end{tabular}


E. Eğmir \& İ. Ocak - Prediction Level of the Fourth Grade Students' Scientific Attitudes...

\begin{tabular}{llll}
\hline & High School & 151 & 32.3 \\
\cline { 2 - 4 } & Undergraduate & 129 & 27.6 \\
\hline \multirow{4}{*}{ First semester grade } & 1 & 28 & 6.0 \\
& 2 & 13 & 2.8 \\
\cline { 2 - 4 } & 3 & 38 & 8.3 \\
\hline \multirow{4}{*}{$\begin{array}{l}\text { Last mathematics exam } \\
\text { grade }\end{array}$} & 4 & 90 & 19.7 \\
& 5 & 288 & 63.0 \\
\hline & 1 & 21 & 3.8 \\
\hline & 2 & 52 & 4.5 \\
\hline & 3 & 115 & 11.1 \\
\hline & 4 & 254 & 24.6 \\
\hline
\end{tabular}

Since the first semester grade and last math exam grade variables were not answered by all students, the total number of students in these two variables was slightly lower than the total sample number.

\subsection{Data collection tool}

In the data collection process, "Scientific Attitude Scale" developed by Moore and Foy (1997) and adapted by Demirbaş and Yağbasan (2006) was used. The scale is a five-point Likerttype scale which shows a six-factor structure with a total of 40 items. The degree of participation in items of scale is classified as "Strongly Agree", "Agree", "Undecided", "Disagree", and "Strongly Disagree". As a result of validity and reliability analyses, Cronbach Alpha reliability coefficient is .76 and Spearman Brown two-half test correlation is found .84. In the present study Cronbach Alpha reliability coefficient was .88.

Besides, "Reflective Thinking Skill for Problem Solving Scale" developed by Kızılkaya and Asskar (2009) was used. The scale has a total of 14 items and three dimensions (questioning, reasoning and evaluation). Scoring has been designed according to the responses of the student considering the frequency of the performing of the action in those items. Action frequencies have been organized in the levels of "Always", "Often", "Sometimes", "Rarely", and "Never". According to the reliability analysis, Cronbach Alpha coefficient for the "questioning" dimension has been found as .73, for the "reasoning" dimension as .71, and for the "evaluation" dimension as .69. The value is .83 for the whole scale. In the present study, the Cronbach alpha coefficient for the whole scale was calculated as .92. The Cronbach alpha coefficients for dimensions were .72, .80 and .80, respectively. These values are considered to be highly reliable for the scale to be used in the present research (Tavsancil, 2006: 29).

\subsection{Data analysis}

The data obtained from the evaluated scales were analyzed using a statistical program. In order to determine the level of the fourth-grade students' reflective thinking skills for problem solving (and sub-dimensions) and scientific attitudes, the mean of their answers was taken. Then it was determined that the data that related to scientific attitudes and reflective thinking skills for problem solving showed a normal distribution according to results of normality test. So, independent samples t-test, one way ANOVA test, Pearson correlation test, compound effect analyses and linear regression test was conducted for the purposes of the research. 


\section{Findings}

In the study, first, the level of the fourth-grade students' scientific attitudes and reflective thinking skills for problem solving was examined. The results are shown in Table 2.

Table 2. Descriptive statistics of reflective thinking skills for problem solving and scientific attitudes

\begin{tabular}{lllllll}
\hline Dimension & & f & Minimum & Maximum & $\bar{x}$ & Std. Dev. \\
\hline Scientific attitudes & & 468 & 10.00 & 173.00 & 100.65 & 22.09 \\
\hline Reflective thinking & & 468 & 14.00 & 70.00 & 31.87 & 12.20 \\
\hline \multirow{2}{*}{ Sub-Dimensions } & Questioning & 468 & 5.00 & 25.00 & 11.79 & 4.35 \\
\cline { 2 - 7 } & Reasoning & 468 & 4.00 & 20.00 & 8.57 & 4.08 \\
\cline { 2 - 7 } & Evaluation & 468 & 5.00 & 25.00 & 11.50 & 4.94 \\
\hline
\end{tabular}

When the findings in Table 2 are examined, it can be stated that students have a low level of reflective thinking skills for problem solving and sub-dimensions. Students have a low level of scientific attitudes, too.

Second, independent samples t-test was applied to determine whether the reflective thinking skills for problem solving (and sub-dimensions) and scientific attitudes differed significantly in terms of gender. According to the test, it can be said that students' reflective thinking skills for problem solving (and sub-dimensions) and scientific attitudes do not differ significantly in terms of gender. Besides, it can be stated that the means determined in reflective thinking skills for problem solving and sub-dimensions are high in favor of male students. On the other hand, female students' scientific attitude levels are higher than male students according to means.

After that, one way ANOVA test was applied to determine whether the reflective thinking skills for problem solving (and sub-dimensions) and scientific attitudes differed significantly in terms of family income level, mother education level, father education level, first semester grade, and last mathematics exam grade variables. It can be said that students' reflective thinking skills for problem solving (and sub-dimensions) and scientific attitudes do not differ significantly in terms of family income level. Besides, it can be stated that the means determined in all dimensions are high in favor of students with high family income level except "questioning" sub-dimension. In "questioning" sub-dimension, students with low family income level have the highest mean.

When the data according to mother education level are examined, it can be said that students' reflective thinking skills for problem solving and sub-dimensions except "questioning" and scientific attitudes differ significantly in terms of mother education level. When the differences are examined, the attitudes towards science and reflective thinking skills towards problem solving of the students whose mother education level are high school and undergraduate are significantly high.

Besides, when the data according to father education level are examined, it can be said that students' reasoning skills differ significantly in terms of father education level. When it is analyzed from which groups the difference originates, it is seen that the students whose father education level are undergraduate and high school have a significantly higher level of reasoning skills than the students whose father education level are secondary school.

After that, when the data according to first semester grade are examined, it can be said that students' reflective thinking skills for problem solving (and sub-dimensions) and scientific attitudes differ significantly in terms of first semester grade variable. It is seen that the difference 
E. Eğmir \& İ. Ocak - Prediction Level of the Fourth Grade Students' Scientific Attitudes...

is significantly in favor of the students with "excellent" and "good" grades. Also, when the averages are examined, the levels of skill and attitude increase as the grade increases.

When the data according to last mathematics exam grade are examined, it can be said that students' reflective thinking skills for problem solving and sub-dimensions differ significantly in terms of last mathematics exam grade. It is seen that the difference is significantly in favor of the students with "excellent" and "good" grades. Also, when the averages are examined, the levels of skill and attitude increase as the grade increases.

In the study, also, it was examined whether there was a significant correlation between reflective thinking skills for problem solving (and sub-dimensions) with scientific attitudes. The results are shown in Table 3.

Table 3. Correlation between reflective thinking skills for problem solving and sub-dimensions with scientific attitudes

\begin{tabular}{llllll}
\hline & & $\begin{array}{l}\text { Reflective } \\
\text { Thinking }\end{array}$ & Questioning & Reasoning & Evaluation \\
\hline $\begin{array}{l}\text { Scientific } \\
\text { Attitudes }\end{array}$ & $\begin{array}{l}\text { Correlation } \\
\text { coefficient }\end{array}$ & $.585^{* *}$ & $.518^{* *}$ & $.548^{* * *}$ & $.535^{* *}$ \\
\hline & $\mathbf{p}$ & .00 & .00 & .00 & .00 \\
\hline
\end{tabular}

${ }^{* *}$ Correlation is significant at the 0.01 level (2-tailed).

When the results in Table 3 are examined, it can be said that there is a significant and positive correlation between the fourth-grade students' scientific attitudes with reflective thinking skills for problem solving and sub-dimensions. All correlation coefficients are found to be significant.

In the study, compound effect analyses were conducted to determine whether the reflective thinking skills for problem solving of the fourth-grade students differed significantly according to the level of scientific attitude and the variables determined. Compound effects of variables except family income level, mother education level and first semester grade with scientific attitude level were not significant.

It is found that the compound effect of the level of scientific attitude and family income level is significant on the reflective thinking skills of students $[\mathrm{F}(104,259)=1.757 ; \mathrm{p}<.05]$. In addition to this, the scores obtained show a significant difference separately in terms of scientific attitude level $[\mathrm{F}(102,259)=4.590 ; \mathrm{p}<.05]$ in favor of higher level. According to the findings, in all single scientific attitude level, students who have higher family income level were more skillful at reflective thinking skill for problem solving.

Besides, it is found that the compound effect of the level of scientific attitude and mother education level is significant on the reflective thinking skills of students $[F(9,451)=2.139$; $\mathrm{p}<.05]$. In addition to this, the scores obtained show a significant difference separately in terms of scientific attitude level $[\mathrm{F}(4,451)=45.640 ; \mathrm{p}<.05]$ in favor of higher level. According to the findings, in all single scientific attitude level, students who have higher mother education level were more skillful at reflective thinking skill for problem solving.

It is found that the compound effect of the level of reflective thinking for problem solving and first semester grade is significant on the scientific attitudes of students $[\mathrm{F}(13,435)$ $=2.314 ; \mathrm{p}<.05]$. In addition to this, the scores obtained show a significant difference separately in terms of reflective thinking for problem solving level $[\mathrm{F}(4,435)=14,183 ; \mathrm{p}<.05]$ and first semester grade $[\mathrm{F}(4,435)=4.223 ; \mathrm{p}<.05]$ in favor of higher level. According to the findings, in all single reflective thinking for problem solving level, students who have higher first semester grade were better at scientific attitudes. 
In the study, also, it was examined whether test to determine whether students' scientific attitudes significantly predicted their reflective thinking for problem solving. Before performing the regression analysis, it was checked whether the assumptions required for the analysis were met. Accordingly, it was first seen that the data had a normal distribution and normality assumption was provided. Then, as can be seen in Table 3, where the findings of the correlation analysis are presented, the presence of a linear relationship between the predictive variable and the predicted variable was determined. The results of the analysis of variance related to regression analysis are shown in Table 4.

Table 4 . The results of the analysis of variance related to the prediction of reflective thinking for problem solving

\begin{tabular}{llllll}
\hline Model & $\begin{array}{l}\text { Sum of } \\
\text { Squares }\end{array}$ & df & $\begin{array}{l}\text { Mean } \\
\text { Square }\end{array}$ & F & p \\
\hline Regression & 23838.528 & 1 & 23838.528 & 242.781 & \multirow{2}{*}{$.00^{*}$} \\
\hline Residual & 45756.284 & 466 & 98.189 & 249 \\
\hline
\end{tabular}

${ }^{*} \mathrm{p}<.01$

When the Table 4 is examined, it can be stated that the model established for the prediction of the reflective thinking of the fourth grade students by the scientific attitude is significant $\left(\mathrm{F}_{(1,466)}=242.781 ; \mathrm{p}<.01\right)$. After that, the findings of linear regression analysis between the reflective thinking and scientific attitude concepts are given in Table 5 .

Table 5 . The results of regression analysis on the prediction of reflective thinking for problem solving by scientific attitude

\begin{tabular}{llllll}
\hline Predictive Variables & $\mathbf{B}$ & Std. Error & $\boldsymbol{\beta}$ & $\mathbf{t}$ & $\mathbf{p}$ \\
\hline (Constant) & -.667 & 2.138 & & -.312 & .75 \\
\hline Scientific Attitude & .323 & .021 & .585 & 15.581 & $.00^{*}$ \\
\hline $\mathrm{R}=.585 ; \mathrm{R}^{2}=.343 ;$ & & & & \\
$\mathrm{F}_{(1,466)}=242.781 ; \mathrm{p}<.01$ & & & & & \\
\hline
\end{tabular}

According to the analysis, while the model is significant as a whole $\left[\mathrm{F}_{(1,466)}=\mathbf{2 4 2 . 7 8 1}\right.$; $\mathrm{p}<$.01], reflective thinking for problem solving of the fourth grade students was strongly explained by scientific attitudes.

According to the findings, regression equation of reflective thinking for problem solving of the fourth-grade students was as follows:

Reflective Thinking $=.323 \times$ Scientific Attitude

\section{Results and discussion}

In the study, firstly, when the results related to the means were examined, it can be stated that the students had a low level of reflective thinking skills for problem solving (and subdimensions) and scientific attitudes. Accordingly, students use the reflective thinking skill very little in the problem solving process. In other words, they do not apply the questioning, reasoning and evaluation skills much in the problem solving process. However, it is seen that students' attitudes towards science were not high.

According to Demirel, Derman and Karagedik (2015) and Kızılkaya and Aşkar (2009) the level of reflective thinking skills for problem solving of secondary school students were not sufficient. Katrancı and Şengül (2020) also determined the questioning skills of secondary school 
students at an intermediate level. In the research of Aydın and Diker Coşkun (2016), it was found that the eighth grade students' reflective thinking skills for problem solving were low. Based on these findings, it is seen that students do not use reflective thinking skills in their learning processes. However, it can be stated that the attitudes of the students determining their affective positions towards learning are low. In this context, it can be said that the revisions made in the curriculum and teaching processes towards constructivism have not yet had a positive effect.

When the results related to gender variable are examined it can be seen that students' reflective thinking skills for problem solving (and sub-dimensions) and scientific attitudes did not differ significantly. According to Corbett et al. (2008) gender differences between girls and boys have decreased and in some subjects no longer exist. But, the analyses typically do not present data on the academic achievement of male and female students in such a way as to show the effect of variables such as ethnicity or economic status. Fraser et al. (2011) pointed out that researchers do not give much detail about achievement differences between students according to gender. This situation has limited researchers' understandings of the issues that mediate students' achievement, attitudes, and participation in science.

Gender is characterized as the most significant variable towards students' attitude to science. When the literature is analyzed, men mostly show more positive attitudes towards science than women. Also, according to Aiken and Aiken (1969), it was a well-known cultural bias that science and mathematics were generally "masculine" occupations. But, Lowery (1966) said that fifth-grade girls had more positive attitudes than fifth-grade boys. Given the particular situation in Turkey, female students usually achieve high scores than male students in both national and international exams (MONE, 2019a; 2019b, ASPC, 2019). This shows that female students improve themselves academically better, identify their deficiencies better, take measures accordingly and arrange their learning processes in a way that reveals their potential.

According to Saygll and Atahan (2014), reflective thinking skills of primary and secondary school students towards problem solving did not differ significantly according to gender variable. In the study of Kirnık (2010), it was obtained that the effect of the activities developing reflective thinking did not differ according to gender while Demirel, Derman, and Karagedik (2015) and Solakumur (2017) stated that reflective thinking skills for problem solving did not differ according to gender. In the study of Kaya (2009) in which primary school students' thinking styles and academic achievements in mathematics were examined, it was found that the scores obtained from the scale related to thinking styles did not change according to gender. In the study of Kızılkaya and Asskar (2009), gender was not found to be effective on problem solving. There are studies supporting this finding in the literature (Aldan Karademir \& Görgün, 2019; Dilci \& Babacan, 2012; Erdoğan, 2019; Güneş, 2015; Köseoğlu, Demirci, Demir \& Özyürek, 2017; Özkök, 2004; Tat, 2015).

When the results related to the family income level examined, it can be stated that students' reflective thinking skills for problem solving (and sub-dimensions) and scientific attitudes did not differ significantly in terms of family income level. Besides, it can be stated that the means determined in all dimensions are high in favor of students with high family income level except "questioning". Hacieminoglu (2016) found that family income had a significant effect on the students' attitude towards science. The mean scores of the students from a low income were significantly different from those students from a medium and from a high-income family. Also, Lowery (1966) determined that the students from an upper socioeconomic area had more positive attitudes toward science than those from middle and lower socioeconomic areas (Aiken \& Aiken, 1969).

Uygun and Bilgiç (2018) determined that reflective thinking skills of middle school students towards problem solving did not differ significantly according to socio-economic level. There are studies supporting this finding in the literature (Aydın \& Çelik, 2013, Ceyhan, 2014; 
Gedik, Akhan \& Kılıçoğlu, 2014; Güneş, 2015; Kırnık, 2010; Şen, 2013; Tat, 2015). Also, Bilgiç (2017) determined that students' reflective thinking skills for problem solving did not differ significantly according to the economic situation they perceived. In the light of this finding, it can be said that students' thinking skills and attitudes which constitute the cognitive and affective dimension of the learning context do not change according to the level of opportunities that students have.

When the results related to mother education level are examined it can be stated that reflective thinking skills for problem solving and sub-dimensions except "questioning" and scientific attitudes differed significantly in terms of mother education level. When the differences are examined, the attitude and skill of the students whose mother education level are high school and undergraduate were significantly high.

In his study, Rani (2006) found that the level of education of the mother had an effect on the attitude of the students to the utility of science, but this was not statistically significant. Hacieminoglu (2016) found that students with higher levels of mother education had higher attitudes towards science than those with lower mother education level. George and Kaplan (1998), in their research, determined that parental education was found to have significant total indirect effects on the extent of parental involvement. Higher parental education is associated with children's visits to libraries and museums and also participation in science activities such as science fairs and clubs. In general, all these activities have significant positive indirect effects on student science attitudes. Şen (2013) determined that there was a positive relationship between the education level of the parents and the reflective thinking skills of the students.

When the results related to father education level are examined, it can be stated that students' reasoning skills differed significantly in terms of father education level. When it is analyzed from which groups the difference originates, it is seen that the students whose father education level are undergraduate and high school had a significantly higher level of reasoning skills than the students whose father education level are secondary school. Hacieminoglu (2016) found that students with higher levels of father education had higher attitudes towards science than those with lower father education level.

According to Saygll and Atahan (2014), reflective thinking skills of primary and secondary school students towards problem solving did not differ significantly according to their father's education level. Bilgiç (2017), in his study, determined that students' reflective thinking skills for problem solving did not differ significantly according to their educational status. According to Uygun and Bilgiç (2018), reflective thinking skills of middle school students towards problem solving did not differ significantly according to their father's education level. There are studies in the literature supporting this finding (Aydın \& Çelik, 2013; Güneş, 2015; Tat, 2015)

When the results related to first semester grade examined, it can be stated that students' reflective thinking skills for problem solving (and sub-dimensions) and scientific attitudes differed significantly in terms of first semester grade. It is seen that the difference was significantly in favor of the students with "excellent" and "good" grades. Also, when the averages are examined, the level of skill and attitude increase as the grade increases.

Rani (2006) found in his research that achievement motivation was found to have statistically significant effects on science attitudes only in the eighth grade and the ninth grade. Katrancı and Şengül (2020) determined that the success levels of secondary school students positively affected their inquiry skills towards mathematics. In the study of Inel Ekici (2017), it was stated that students who have high scientific inquiry skills have higher level of participation, interest and attention in the learning process, and so their success increased because of the effect of these variables. Özsoy (2005); Wolf and Fraser, (2008); Taskoyan, (2008); Hacısalihoğlu, Mirasyedioğlu and Akpınar (2003); Kogan and Laursen (2014); Uygun and Bilgiç (2018) also reached similar findings. 
In parallel with this result, students with high academic success think about the strategies they use in similar problems they have faced before and that they consider the suitability of these strategies to the problem (Polya, 1957; Yeşilova, 2013). It has been found that seventh grade students participating in the study conducted by Bilgiç (2017) differed significantly in their reflective thinking skills for problem solving in favor of those who received high grades from Social Studies course. In the study conducted by Altuntaş (2019), when the relationship between students' reflective thinking skills and academic achievement was examined, it was obtained that there was a positive and moderately significant relationship. When looking at the difference between the groups, it was determined that the groups with high academic success had more reflective thinking skills to solve more problems than the groups with lower academic success.

When the results related to last mathematics exam grade are examined, it can be stated that students' reflective thinking skills for problem solving and sub-dimensions differed significantly in terms of last mathematics exam grade. It is seen that the difference was significantly in favor of the students with "excellent" and "good" grades. Also, when the averages are examined, the level of skill and attitude increase as the grade increases.

While Baş and Kıvılcım (2013) determined that high school students' mathematics and geometry achievements made a significant difference on reflective thinking skills for problem solving, Tok (2008) concluded that reflective thinking activities increased academic achievement for primary school students' science course. Aldan Karademir, and Görgün (2019) determined that students who got a high grade in mathematics course had high reflective thinking skills for problem solving. Şen (2013), in his research on elementary school students, found significant relationships between students' reflective thinking skills based on problem solving and their academic achievements in mathematics. In addition, Özsoy (2002) found a significant relationship between the general success of mathematics lesson and problem solving. In his study, Leung (1993) stated that students with higher mathematics knowledge can produce problems that can be classified as reasonable and solvable problems. This result is consistent with the results of this study.

When the result related to the correlation analysis is examined it can be stated that there is a significant and positive correlation between the fourth grade students' scientific attitudes with reflective thinking skills for problem solving and sub-dimensions. According to Demirel, Derman, and Karagedik (2015), there was a moderately significant and positive relationship between students' reflective thinking skills and their attitudes towards mathematics. Besides, "evaluating" sub-dimension of the reflective thinking skills towards problem solving had a stronger relationship with the dimensions of the attitude towards mathematics compared to the other dimensions. Pimta, Tayruakham, and Nuangchalerm (2009) concluded in their study that problem solving skills directly affected the attitude towards mathematics in the positive way. Also, Bas and Beyhan (2012), Phan (2006; 2009), Tok (2008) pointed out a positive relationship in their study in which they have studied reflective thinking skills and attitudes towards different lessons.

Güneş (2015) found a statistically significant relationship between attitude towards mathematics lesson and reflective thinking towards problem solving in general. Aldan Karademir, and Görgün (2019) determined a positive, high-level and significant relationship between secondary school students' self-regulation and reflective thinking skills for problem solving. As a matter of fact, Francisco and Maher (2005), Hoffman and Spatariu (2011), and Ylldız (2010) also reached the conclusion that meta-cognition affects problem solving and it also improves learning.

Kesinkılıç (2010) concluded that activities based on reflective thinking applied in the seventh-grade science and technology lesson in primary education contributed to the development of scientific process skills. In their study, Kurtuluş and Erylmaz (2017) determined that as the problem-based reflective thinking skills of students increased, their anxiety in mathematics lesson 
also decreased. In the study conducted by Tat (2015), it was concluded that there was a relationship between weekly mathematics lesson working times and attitudes towards solving mathematics problem and dependent variable. According to Walle and John (1998), the time spent on problem solving is closely related to the pleasure of solving problems. An individual who enjoys problem solving tries to reach the result without getting tired or bored during the problemsolving process. The individual who has a negative attitude gets squeezed out of the problem after a maximum of one attempt.

Aydın and Diker Coşkun (2016) found a significant and positive relationship between seventh grade students' motivation towards mathematics course and reflective thinking skills based on problem solving. Erdoğan and Şengül (2019) aimed to investigate the effect of reflective thinking activities on mathematics attitude in sixth grade students. As a result of the research, it was concluded that the students' math attitudes in the experimental group were higher than the students in the control group. In the research of Pimta et. al. (2009), it was determined that reflective thinking skill towards problem solving had a positive effect on mathematics attitude. It has been determined that reflective thinking activities contribute to the positive attitude of the students towards the course (Bas \& Beyhan, 2012). Aydın and Diker Coşkun (2016) stated that there was a positive relationship between eighth grade students' mathematics motivation and reflective thinking skills for problem solving.

When the result related to regression analysis is examined, it can be stated that reflective thinking for problem solving of the fourth grade students was strongly explained by scientific attitudes. No direct study was found in terms of the relationship between students' reflective thinking skills towards problem solving and attitude towards science. But, Demirel et al. (2015) pointed out that it is seen that the relationship between the students' reflective thinking skills towards problem solving and their attitude towards mathematics is significant on a moderate level in the positive sense. Kaur (2013) found that the relationship between the two variables of critical thinking and scientific attitude having the relationship of the magnitude .369 signified that there was positive and significant relationship between the two variables.

Baş and Kıvılcım (2013) thought that reflective thinking skills for problem solving are an important predictor of academic success in mathematics lessons $\left(\mathrm{R}=.782, \mathrm{R}^{2}=.611, \mathrm{p}=.000\right)$ and reflective thinking skills for problem solving predict approximately $62 \%$ of academic success in mathematics and 67\% of the academic success in geometry. Albayrak, Şimşek and Yazıcı (2018) determined that reflective thinking skill for problem solving is a variable that predicts mathematics achievement significantly. On the other hand, in the study of Baş (2013), primary school students' reflective thinking skills for problem solving explained their academic achievements in science and technology. So, this finding supports the findings of this study.

\section{Conclusion}

Consequently, it is seen that there is a significant and positive correlation between the fourth-grade students' scientific attitudes with reflective thinking skills for problem solving. Also, reflective thinking for problem solving of the fourth-grade students was strongly explained by scientific attitudes. These findings should be taken into account when designing teaching and learning environments. Teaching and learning activities consist of sub-fields with different structures and that both cognitive and affective elements should be taken into account in order to teach effectively. Considering that reflective thinking skill is an important thinking skill, the importance of scientific attitude has been revealed in order to gain and develop this skill for students. In this way, it can be stated that thinking skills will become functional especially with the development of scientific attitude. This situation reveals once again the effect of affective elements in the learning process expressed in brain-related studies in recent years. 
E. Eğmir \& İ. Ocak - Prediction Level of the Fourth Grade Students' Scientific Attitudes...

\section{Acknowledgements}

This research did not receive any specific grant from funding agencies in the public commercial, or not-for-profit sectors.

The authors declare no competing interests.

\section{References}

Adodo, S. O., \& Gbore, L. O. (2012). Prediction of attitude and interest of science students of different ability on their academic performance in basic science. International Journal of Psychology and Counselling, 4(6), 68-72.

Aiken Jr, L. R., \& Aiken, D. R. (1969). Recent research on attitudes concerning science. Science Education, 53(4), 295-305.

Albayrak, M., Şimşek, M., \& Yazıcı, N. (2018). The predictive power to mathematical success of belief and reflective thinking for problem solving. International Journal of Human Sciences, 15(2), 807815 .

Aldan Karademir, Ç., \& Görgün, S. (2019). Investigation of secondary school students' reflective thinking skills for problem solving and self-regulation skills. International Journal of Euroasian Researches, 7(16), 292-313.

Altun, M. (2002). Mathematics teaching in secondary education. İstanbul: Alfa Printing and Publishing.

Altuntaş, L. (2019). Examining the relationship between math achievement math attitudes and reflective thinking skills towards problem solving of the $7^{\text {th }}$ grade students (Unpublished Master Thesis). İstanbul: Yıldız Teknik University.

ASPC (2019). Numerical information about 2019 YKS exam results. https://www.osym.gov.tr/TR,16859/2019-yks-sinav-sonuclarina-iliskin-sayisal-bilgiler.html [Accessed 31 March 2020].

Aydın, B. B., \& Diker Coşkun, Y. (2016). The relationship between math achievement motivation and reflective thinking skills towards problem solving. Yeditepe University Journal of Education, $5(7), 12-28$.

Aydın, M., \& Çelik, T. (2013). The prospective teachers' opinions relating reflective thinking skills. Pamukkale University Journal of Education, 34(34), 169-131.

Baş, G., \& Beyhan, Ö. (2012). The effect of reflective thinking activities on students' academic achievement and attitudes towards the English course. Amasya University Journal of Education, 1(2), 128142.

Baş, G., \& Kıvılcım, Z. S. (2013). The correlation between reflective thinking skills towards problem solving and academic success in mathematics and geometry courses of high school students. Kirşehir University Journal of Education, 14(3), 1-6.

Baş, G. (2013). Investigating the correlation between elementary students' reflective thinking skills towards problem solving and academic success in science and technology course with structural equation modeling. Hasan Ali Yücel Journal of Education, 2O, 1-12.

Bilen, M. (1996). Teaching from plan to practice. Ankara: Aydan Web Facilities.

Bilgiç, C. (2017). Reflective thinking skills of elementary school students to solve problems, social studies and academic achievements (Unpublished Master Thesis). Uşak: Uşak University. 
Bingham, A. (2004). Developing problem solving skills in children. A. Ferhan Oğuzkan (Trans.). İstanbul: Milli Eğitim Press.

Bloom, S. B. (1976). Human characteristics of school learning. New York: McCraw Hill.

Büyüköztürk, Ş. (2016). Handbook of data analysis for the social sciences: Statistics, research pattern SPSS applications and interpretation (Extended 22 ${ }^{\text {nd }}$ Edition). Ankara: Pegem Akademi Publishing.

Ceyhan, G. (2014). Scrutinizing the university students' reflective thinking level and their anxieties towards research in terms of several variables by using CART analysis (Unpublished Master Thesis). Van: Yüzüncü Yıl University.

Corbett, C., Hill, C., \& St. Rose, A. (2008). Where the girls are: The facts about gender equity in education. American Association of University Women Educational Foundation. Washington, DC.

Demirbaş, M., \& Yağbasan, R. (2006). The functional importance of scientific attitudes in science teaching and adoptation of scientific attitude scale into Turkish. Uluda $\breve{g}$ University Journal of Education, $X I X(2), 271-299$.

Demirel, M., Derman, İ., \& Karagedik, E. (2015). A study on the relationship between reflective thinking skills towards problem solving and attitudes towards mathematics. Procedia-Social and Behavioral Sciences, 197, 2086-2096.

Dilci, T., \& Babacan, T. (2012). The views of the primary school teachers' depending on the fifth grade curriculum in development of reflective thinking skills. CÜ Journal of Social Sciences, 36(1), 141-161.

Erdoğan, A. (2019). The examination of secondary school students' reflective thinking skills towards problem solving in terms of certain variables (Unpublished Master Thesis). Konya: Necmettin Erbakan University.

Erdoğan, F., \& Şengül, S. (2019). The effect of reflective thinking activities on sixth grade students' attitude towards mathematics. Kastamonu Journal of Education, 27(1), 247-260.

Francisco, J. M., \& Maher, C. A. (2005). Conditions for promoting reasoning in problem solving: Insights from a longitudinal study. Journal of Mathematical Behavior, 24, 361372.

Fraser, B., Tobin, K., \& McRobbie, C. J. (Eds.). (2011). Second international handbook of science education (Vol. 24). Springer Science \& Business Media.

Gagne, R. M. (1980). Learnable aspects of problem solving. Educational Psychologist, 15(2), 84-92. https://doi.org/10.1080/00461528009529218

Gardner, P. L. (1975). Attitudes to science. Studies in Science Education, 2, 1-41.

Gedik, H., Akhan, N. E., \& Kılıçoğlu, G. (2014). The reflective thinking tendency of social studies candidate teachers. Mediterranean Journal of Humanities, 4(2), 113-130.

George, R., \& Kaplan, D. (1998). A structural model of parent and teacher influences on science attitudes of eighth graders: Evidence from NELS: 88. Science Education, 82(1), 93-109.

Gokul, R. R., \& Malliga, T. (2015). A study on scientific attitude among pre-service teachers. Research Journal of Recent Sciences, 4, 196-198.

Güneş, K. (2015). Analysing the science and art students' reflective thinking skills aimed at solving problem, mathematics successes and attitudes to mathematics lesson (Unpublished Master Thesis). Adana: Çukurova University.

Hacieminoglu, E. (2016). Elementary school students' attitude toward science and related variables. International Journal of Environmental and Science Education, 11(2), 35-52.

Hacısalihoğlu, H., Mirasyedioğlu, S., \& Akpınar, A. (2003). Elementary mathematics teaching. Ankara: Asil Publishing. 
E. Eğmir \& İ. Ocak - Prediction Level of the Fourth Grade Students' Scientific Attitudes...

Hoffman, B., \& Spatariu, A. (2011). Metacognitive prompts and mental multiplication: Analyzing strategies with a qualitative lens. Journal of Interactive Learning Research, 22(4), 607-635.

İnel Ekici, D. (2017). An investigation on the factors affecting the scientific inquiry skills perceptions of secondary students. Kastamonu Journal of Education, 25(2), 497-516.

Johnston, J. (1996). Early explorations in science. Buckingham: Open University Press.

Kalayc1, N. (2001). Problem solving and applications in social sciences. Ankara: Gazi Publishing.

Karasar, N. (2016). Scientific research method: Concepts, principles, techniques (30 ${ }^{\text {th }}$ Edition). Ankara: Nobel Publishing.

Katrancı, Y., \& Şengül, S. (2020). The evaluation of inquiry learning skills towards math of middle school students in terms of inquiring, evaluating, reasoning, and reflective-thinking skills for problem-solving. Education \& Science, 45(201), 55-78.

Kaur, G. (2013). Scientific attitude in relation to critical thinking among teachers. Educationia Confab, 2(8), 24-29.

Kaya, B. (2009). A study on $6^{\text {th }} 7^{\text {th }}$ and $8^{\text {th }}$ grade students? thinking styles and mathematics achievement according to their school type, gender and grade level (Unpublished Master Thesis). Yildız Teknik University, İstanbul.

Keskinkılıç, G. (2010). The affect of reflective thinking based learning activities in 7 th class science and technology lesson on the students' achievements and their scientific process skills (Unpublished Doctoral Dissertation). Konya: Selçuk University.

Kırnık, D. (2010). Effect on student's success of activities improving reflective thinking in Turkish lesson of fifth class in primary school (Unpublished Master Thesis). Elazığ: Firat University.

Kızılkaya, G., \& Aşkar, P. (2009). The development of a reflective thinking skill scale towards problem solving. Education \& Science, 34(154), 82-92.

Kogan, M., \& Laursen, S. L. (2014). Assessing long-term effects of inquiry-based learning: A case study from college mathematics. Innovative Higher Education, 39(3), 183-199.

Korkut, F. (2002). Problem solving skills of high school students. Hacettepe University Journal of Education, 23, 177-184.

Köseoğlu, E., Demirci, F., Demir, B., \& Özyürek, C. (2017), The examination of $7^{\text {th }}$ grade students' reflective thinking skills towards problem solving: A sample of Ordu city, International e-Journal of Educational Studies, 1(1), 60-68.

Kramarski, B. (2008). Promoting teachers' algebraic reasoning and self-regulation with metacognitive guidance. Metacognition Learning, 3, 83-99.

Kurtuluş, A., \& Eryılmaz, A. (2017). The relationship between reflective thinking skills based on problem solving and flow experiences in mathematics. Journal of Theoretical Educational Science, $10(3), 349-365$.

Leung, S. S. (1993). The relation of mathematical knowledge and creative thinking to the mathematical problem posing of prospective elementary school teachers on tasks differing in numerical information content (Unpublished Doctoral Dissertation). Pittsburg: Pittsburg University.

Lowery, L. (1966). Development of an attitude measuring instrument for science education. School Science and Mathematics, 64, 494-502.

Mevarech, Z., R., \& Amrany, C. (2008). Immediate and delayed effects of meta-cognitive instruction on regulation of cognition and mathematics achievement. Metacognition and Learning, 3(2), 147157.

Meyer, G. R. (1963). Factors related to scientific attitudes within the secondary schools of an Australian city. Australian journal of education, 7(1), 21-40.

MONE (2019a). PISA 2018 preliminary report of Turkey. Ankara: MEB Publishing. 
MONE (2019b). Central exam report for secondary education institutions in 2019. Ankara: MEB Publishing.

MONE (2018). Curriculum of science course. Ankara: MEB Publishing. Available online at http://mufredat.meb.gov.tr/ProgramDetay.aspx?PID=325 [Accessed 13 November 2019].

Moore, W. R., \& Foy, R. (1997). The scientific attitude inventory: A revision (SAI II). Journal of Research in Science Teaching, 34(4), 327-336.

Munby, H. (1983). Thirty studies involving the "Scientific attitude inventory": What confidence can we have in this instrument? Journal of Research in Science Teaching, 2O, 141-162.

OECD (2017), PISA 2015 assessment and analytical framework: Science, reading, mathematics, financial literacy and collaborative problem solving. Paris: OECD Publishing. https://doi.org/10.1787/9789264281820

Olasehinde, K. J., \& Olatoye, R. A. (2014). Scientific attitude, attitude to science and science achievement of senior secondary school students in Katsina State, Nigeria. Journal of Educational and Social Research, 4(1), 445-452.

Osman, K., Iksan, Z. H., \& Halim, L. (2007). Attitudes towards science and scientific attitudes among students in science. Jurnal Pendidikan, 32, 39-60.

Özkök, A. (2004). The effect of interdisciplinary art on creative problem solving skills and a model suggestion (Unpublished Doctoral Dissertation). Ankara: Gazi University.

Özsoy, G. (2005). The relationship between problem solving skills and mathematical achievement. Gazi University Gazi Journal of Education, 25(3), 179-190.

Phan, H. P. (2009). Exploring students' reflective thinking practice, deep processing strategies, effort, and achievement goal orientations. Educational Psychology, 29(3), 297-313.

Phan, H. P. (2006). Examination of students learning approaches, reflective thinking, and epistemological beliefs: A latent variables approach. Electronic Journal of Research in Educational Psychology, 4(3), 557-610.

Pimta, S., Tayruakham, S., \& Nuangchalerm, P. (2009). Factors influencing mathematic problem-solving ability of sixth grade students. Journal of Social Sciences, 5(4), 381-385.

Polya, G. (1997). How to solve? (F. Halatçı, Trans.). İstanbul: Sistem Publishing.

Rani, G. (2006). A Cross-domain analysis of change in students' attitudes toward science and attitudes about the utility of science. International Journal of Science Education, 28(6), 571-589.

Reeve, R. A., \& Brown, A. L. (1985). Metacognition reconsidered: Implications for intervention research. Journal of Abnormal Child Psychology, 13, 343-356.

Saygll, G., \& Atahan, R. (2014). Investigation of gifted children's reflective thinking skills for problem solving in terms of various variables. Süleyman Demirel University Faculty of Arts and Sciences Journal of Social Sciences, 31, 181-192.

Senemoğlu, N. (1997). Development, learning and teaching. Ankara: Ertem Press.

Simpson, R. D., \& Oliver, J. S. (1990). A summary of major influence on attitude towards achievement in science among adolescent students. Science Education, 74(1), 1-18.

Simpson, R. D., Koballa Jr, T. R., Oliver, J. S., \& Cranley, F. E. (1994). Research on the effective dimension of science learning. In D. Gabel (Ed.), Handbook of research on science teaching and learning. New York: Macmillan.

Solakumur, A. (2017). Relationship between physical education and sports teachers' reflective thinking tendencies and reflecting abilities (Unpublished Master Thesis). Bartın: Bartın University.

Şen, H. Ş. (2013). Reflective thinking skills of primary school students based on problem solving ability. International of Academic Research, 5(5), 41-48. 
E. Eğmir \& İ. Ocak - Prediction Level of the Fourth Grade Students' Scientific Attitudes...

Taşkoyan, S. N. (2008). The effect of inquiry learning strategies on students? skills of inquiry learning, academic success and attitudes (Unpublished Master Thesis). İzmir: Dokuz Eylül University.

Tat, O. (2015). Investigation of elementary school students' reflective thinking ability through problem solving by using hierarchical linear models (Unpublished Master Thesis). Van: Yüzüncü Yıl University.

Tavsancıl, E. (2006). Measurement of attitudes and data analysis with SPSS. Ankara: Nobel Publishing.

Tok, Ş. (2008). The effects of reflective thinking activities in science course on academic achievements and attitudes toward science. İlköğretim Online, 7(3), 557-568.

Unver, G. (2003). Reflective thinking. Ankara: Pegem A Publishing.

Uygun, K., \& Bilgiç, C. (2018). Reflective thinking skills of elementary school students to solve problems, social studies and academic achievements. Journal of the Human and Social Science Researches, 7(3), 1497-1515.

Walle, V., \& John, A. (1998). Elementary and middle school mathematics: Teaching developmentally. New York: Addison Westley Longman.

Wilson, V. L. (1983). A meta-analysis of the relationship between science and achievement and science attitude kindergarten through college. Journal of Research in Science Teaching, 20(9), 839855 .

Wolf, S. J., \& Fraser, B. J. (2008). Learning environment, attitudes and achievement among middle-school science students using inquiry-based laboratory activities. Research in Science Education, 38(3), 321-341.

Yeşilova, Ö. (2013). The seventh-grade students' problem solving behaviors and problem solving achievement levels (Unpublished Master Thesis). İstanbul: Marmara University.

Ylldı, G. (2010). The relationships between middle school seventh grade students' mathematics achievement, metacognitive strategies, thinking styles and mathematics self-concept (Unpublished Doctoral Dissertation). İstanbul: Yıldız Teknik University. 